\title{
The Colombia-Laredo International Bridge: A Preliminary Report of Field Investigations
}

Follow this and additional works at: https://scholarworks.sfasu.edu/ita

Part of the American Material Culture Commons, Archaeological Anthropology Commons, Environmental Studies Commons, Other American Studies Commons, Other Arts and Humanities Commons, Other History of Art, Architecture, and Archaeology Commons, and the United States History Commons

Tell us how this article helped you.

This Article is brought to you for free and open access by the Center for Regional Heritage Research at SFA ScholarWorks. It has been accepted for inclusion in Index of Texas Archaeology: Open Access Gray Literature from the Lone Star State by an authorized editor of SFA ScholarWorks. For more information, please contact cdsscholarworks@sfasu.edu. 


\section{The Colombia-Laredo International Bridge: A Preliminary Report of Field Investigations}

\section{Licensing Statement}

This is a work produced for the Texas Department of Transportation (TxDOT) by the report producer. TxDOT and the report producer jointly own all rights, title, and interest in and to all intellectual property developed under TXDOT's contract with the report producer. The report may be cited and brief passages from this publication may be reproduced without permission provided that credit is given to both TXDOT and the report producer. Permission to reprint an entire chapter, section, figures or tables must be obtained in advance from either the Supervisor of the Archeological Studies Branch, Environmental Affairs Division, Texas Department of Transportation, 125 East 11th Street, Austin, Texas, 78701 or from the report producer. 
TEXAS

State Department of Highways

and Public Transportation

Highway Design Division

Austin, Texas

November 22, 1989

The Colombia-Laredo International Bridge:

A Preliminary Report of Field Investigations

Management Summary

The Texas State Department of Highways and Public Transportation (SDHPT), Highway Design Division, in cooperation with the Office of the State Governor, The Office of the State Historic Preservation Officer, and the City of Laredo, has recently investigated the approach roadway and the bridge site of the proposed Colombia-Laredo International Bridge across the Rio Grande, in Webb County, Texas. The work was conducted to identify cultural resources in these areas and to offer a preliminary description and evaluation of historic properties considered to be potentially eligible to the National Register of Historic Places.

One historical archaeological locale, 41WB205 (portions of the early 20th century mining community of Darwin) and one prehistoric terrace occupation zone, 41WB206, were investigated. Although the portion of 41WB205 within the projected roadway has been severely impacted by modern alteration, the larger and less disturbed surrounding site area is considered to be potentially eligible for the National Register. Further archival research and document 
This Page Redacted Per THC Policy 
tation is considered appropriate. Although 41WB206 encompasses a large area, extensive mechanical testing identified only a light to ephemeral trace of former aboriginal activities. A summary of work to date, findings, and a discussion of research potential is presented below. This information is provided for use by the appropriate federal agency in the evaluation of historic properties within the project area of potential effect and completion of Section 106 requirements as specified in 36 CFR Part 800 .

Introduction

The proposed Colombia-Laredo International bridge reflects an international cooperative attempt to increase the economic development of the Mexican State of Nuevo Leon and that of the U.S.'s Laredo and Webb County area of southern Texas. The Mexican strategy is to provide a center for manufacturing at the townsite of Colombia and a direct route and bridge of export across the Rio Grande. Long-term goals will include the construction of a freeway between Sabinas Hidalgo, to Anahuac, and to Columbia. Crossing the international boundary, the highway will connect with Texas FM 1472 and turn southward for a short distance toward Laredo.

Interests in Texas, Webb County, and the region in general, include plans for an economic corridor between the manufacturing center of Monterrey, Mexico and a salt-water port on the Texas Gulf Coast at Corpus Christi.

The proposed bridge site location is approximately 20 miles north of Laredo on the property of the Dolores Ranch. Stream terraces east of the north-south flowing Rio Grande are distinctive and well-developed and contrast to a steep 


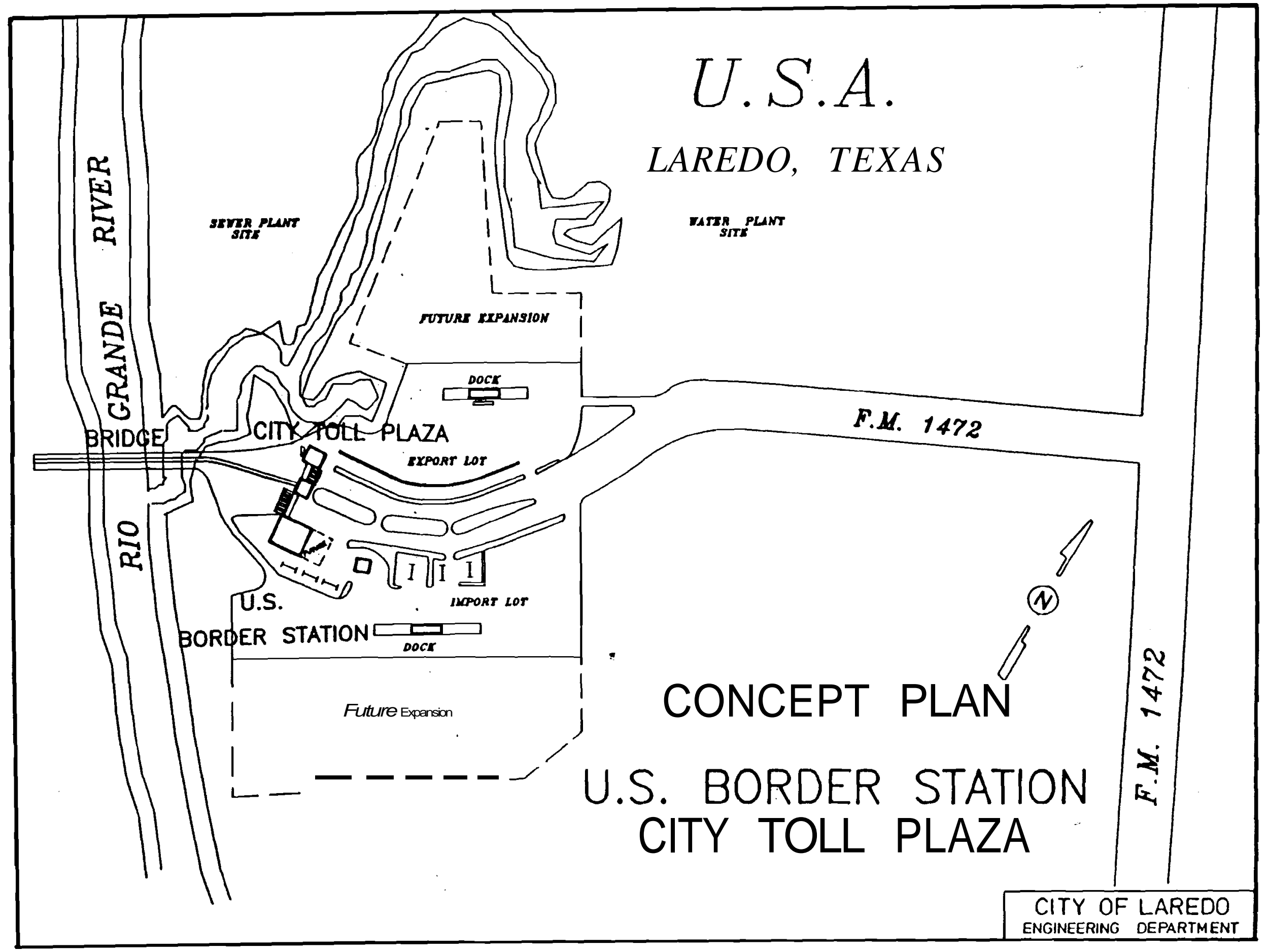


and asymmetric terrace configuration on the Mexican side. Thornbrush predominates the upland areas except in areas of recent land-clearing and/or alterations. Short to moderately tall grasses cover the terraces in the vicinity of the bridge site. Several hundred acres at or near this location have been previously cleared of larger flora such as mesquite and huisache.

The SDHPT preliminary report of findings was concerned with 3 of 4 major areas of the bridge site location: (1) the Mines Road approach roadway, a projected highway that will link the bridge crossing with existing FM 1472; (2) an approximately 100-acre General Services Administration (GSA) support facility that will include U.S. Customs and Immigration structures and (3) the actual endpoint and alignment (locale) of the bridge structure itself. The fourth area at the bridge site location, acreage adjacent to the complex that is projected for future development by the City of Laredo, was not investigated by the SDHPT.

Field Investigations: 41WB205

SDHPT field investigations addressed the historical and prehistoric aspects of the project area separately in consideration of varying methodological approaches. The portion of the Darwin townsite within the proposed Mines Road right-of-way was intensively surveyed in May, 1989. The area was revisited in August to determine the extent of the over-all site area and the intensity of modern disturbance. Although the original townsite that was first established in 1895 once covered a large area, modern land-clearing efforts have detrimentally affected the integrity of the historical-archaeological remains. Only two small areas appear to be currently undisturbed; one on the north end of 
the townsite and another on the southern margin (both are beyond the proposed highway right-of-way). Although the Darwin townsite has been extensively damaged by land-clearing, the potential exists that the locale may be a significant contributing member of a National Register Historic District that would include the surrounding mining communities of Dolores and Santo Tomas (of the same historical era). As such, while no additional field investigations are believed to be warranted, additional archival research and a review of Darwin's development is recommended to more accurately define the community's significance within regional historic contexts.

\section{WB206}

The prehistoric archaeological site of 41WB206 is located along the upland margins and within the river terraces of the Rio Grande at and adjacent to the approximately 100-acre GSA facility/project area. The eastemmost site margin encompasses an extensively disturbed area that has recently been bulldozed. The natural occurrence of siliceous pebbles and cobbles and frequent surface evidence of prehistoric lithic debris suggests this intra-site area was once exploited at least in part for stone quarrying and as a lithic workshop.

The terraces, below and to the west, reflect evidence of temporary campsite activities of small hunting and gathering groups. An occasional fragment of burned or fire-cracked sandstone rock, broken or utilized chert debris, or an infrequent river mussel shell fragment characterize the site. A total of 4 distinct terraces were mechanically excavated for geologic assessments. 
Following an intensive survey, 41WB206 was examined by both hand and mechanical excavations to determine the depth, extent, and significance of possible cultural deposits. Approximately 54 man-days have been expended to date during field operations. Heavy equipment included two mechanical excavators that were used with a judgmental sampling strategy. Depths of trench excavations varied and were often in excess of 3 meters.

In all, 23 mechanical trenches were placed across the project area with particular emphasis on the proposed bridge alignment location. Eight of these trenches, established on an east-west line to bisect all identified terraces, were specifically patterned to assess geologic depositional processes, composition and development of the terraces, approximate ages, and correlations with recognized cultural evidences. Soil humic samples, collected whenever a distinct paleosol was recognized, will be submitted for radiocarbon assay to determine the approximate age of the buried ancient soil(s), to derive estimates of depositional rates, types of sediments, and associated paleoenvironrnental causal factors. Soils chemistry samples were also collected at 10-centimeter vertical intervals to a depth of almost 3 meters.

Although few evidences of cultural features, as represented by thin levels of cultural debris, were uncovered across the project area, mechanical testing proved to be both critical and productive to the understanding of the project area. A detailed geomorphological assessment of the Colombia-Laredo International Bridge project area conducted by the Bureau of Economic Geology, The University of Texas at Austin, is currently underway and will be submitted as an integral portion of the SDHPT's final testing report. 
A total of 10 1-meter square hand-excavated test units were dug across the site area, often to expose small scatters of sandstone rock fragments recognized from mechanical trenching. In addition to sampling the small scatters of burned sandstone, invariably characterized by a paucity of associated cultural materials, a 1-meter square control test unit was established adjacent to Trench 1/14. This trench was located on the highest (T4) modern river terrace in the approximate center of the project area. The control unit, T.U. 1A, excavated a 1-meter square block in 10-centimeter levels and screened through 1/4" wire mesh to a depth of 2.4 meters below the surface. A small collection of chipped stone, as well as an occasional mussel shell and several burned rock fragments were recovered but no other cultural evidences or features were noted. One small arrow point fragment, possibly Catan, was surface collected from the vicinity of Trench 10 in the southern margin of the project area. Two additional biface fragments (Abasolo, Tortugas (?)) were found 90-120 cm below the surface in \$and-excavated units adjacent to Trench 10.

The deepest evidence of cultural activities observed were within Trench 1/14 at a depth of 2.4-2.6 meters below the surface. A charcoal stain ca. $25 \times 15 \mathrm{~cm}$ was noted in the trench wall and was associated with several fragments of lithic debris, unidentifiable bone, and burned sandstone. Humic samples were taken from this level as well as from paleosol zones in other trenches. Cultural deposits appeared to be intact in the lower levels of Trench 1/14 located in the immediate vicinity of the endpoint of the proposed bridge structure. 
It is believed that this portion of the site area reflects the most potential for yielding significant information that may contribute to the regional understanding of the archaeological record. This cultural deposit lies, however, in an area where preliminary engineering studies indicate that construction activities will either be at grade or on fill. As such, and based on the preliminary design plans, construction activities are not currently expected to impact the archaeological remains and no further investigation is believed warranted.

\section{Summary}

Members of the Environmental Section, Highway Design Division, SDHPT, have recently investigated the proposed bridge site and complex of the ColombiaLaredo International Bridge. Cultural resources field operations have identified that portions of the historical townsite of Darwin (circa 1895) will be within the projection of the Mines Road that link the bridge site to existing FM 1472. Additional archival and historical documentation is recommended to more accurately describe the community's contribution to the region's historical development. Portions of a prehistoric occupation zone that encompass the project area along the modern river terraces were also identified and tested. Only a light to ephemeral trace of cultural activities were noted in extensive subsurface examinations that utilized both hand and mechanical testing. Only one subsurface area of potential significance was identified in Trench \#14 as discussed previously. Because preliminary engineering plans indicate that construction activities will not affect the deeply buried deposits in this locale, no further work is recommended at this time. 
A significant aspect of the SDHPT's investigation has been the documentation and analysis of stream/river terrace depositions, sedimentation processes, morphology, and associations with cultural deposits. The significance of such information lies in its comparative value to other previous and also future archaeological and geomorphological studies of adjacent river systems, such as the Nueces and the San-Antonio Guadalupe. It is obvious that paleoenvironmental conditions that influenced the development of particular features of the ancient landscape, such as river terraces, would have affected the morphology of others in the same region. Future archaeological and geomorphological work in these directions may eventually result in a clearer understanding of the causal factors and processes of such early and middle Holocene developments. The influence of such developments are directly linked to the better understanding of regional prehistoric lifeways and adaptations to the natural environment. 


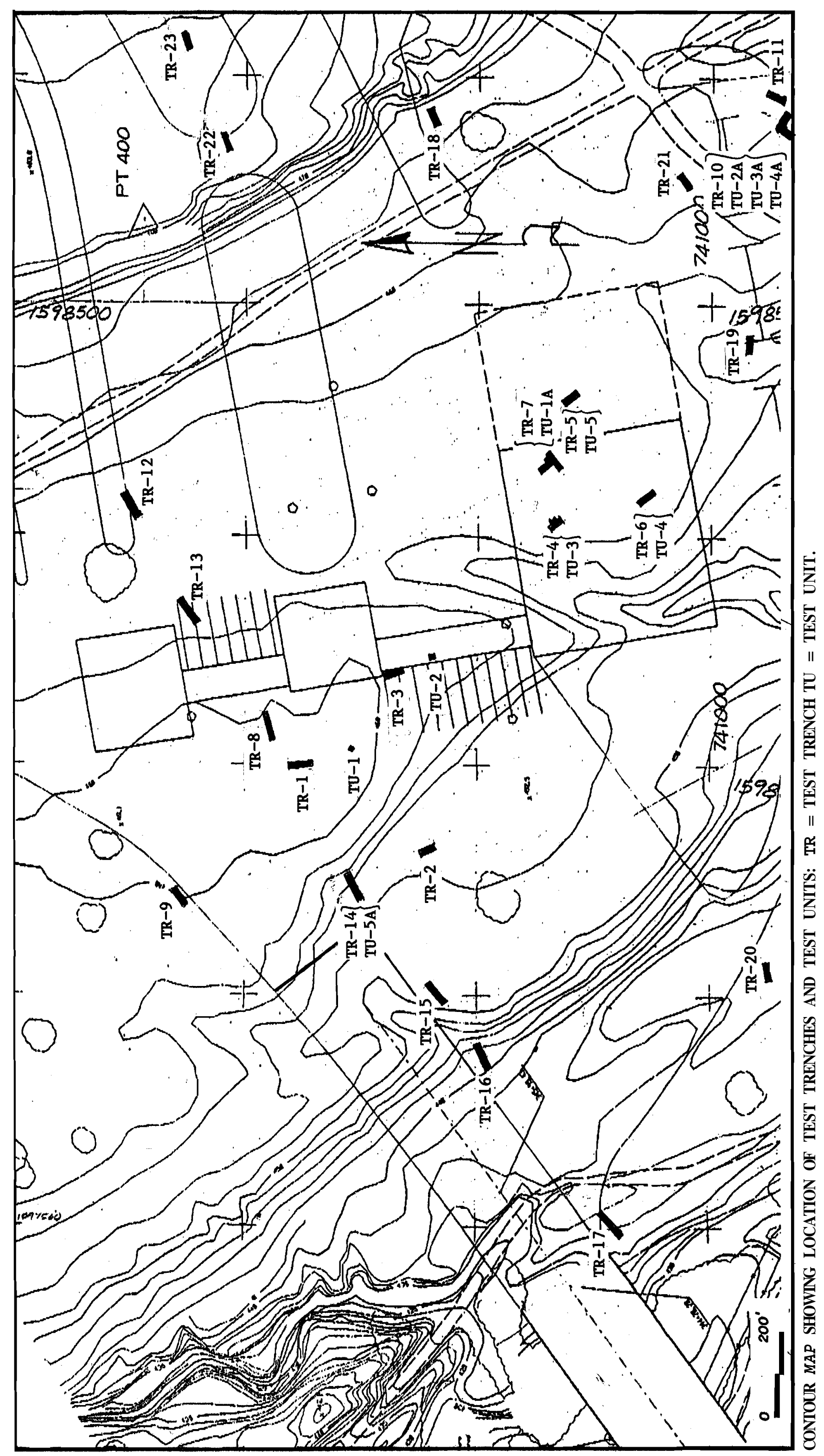

